\title{
The Role of Community Learning Activity Centers in Overcoming Social Problems
}

\author{
Endah Ratnawaty Chotim 1 \\ DOI: 10.35445/alishlah.v13i3.1446
}

\begin{abstract}
Article Info
Abstract

Keywords:

Analysis; Center for

Community Learning

Activities;

Empowerment;

Independence

This study aimed to analyze the role of the Community Learning Activity Center in overcoming Social Problems. This study uses a qualitative research method with a descriptive analysis approach. It is collecting data in this study using the form of observation, interviews, and documentation. The sample in this study used a multiple-stage random sampling method-data analysis techniques through data collection, data presentation reduction, and concluding. The main focus of the Community Learning Activity Center in this study were three main Community Learning Activity Centers Based on the data and research analysis, it can be concluded that the Community Learning Activity Center in Sumedang district to overcome poverty through non-formal education in the form of valuable and practical programs, while other activities in the development and community empowerment sector exist but are still not optimal.
\end{abstract}

Kata kunci:

Analisis; Pusat Kegiatan

Belajar Masyarakat;

Pemberdayaan;

Kemandirian

\begin{abstract}
Abstrak
Penelitian ini bertujuan untuk menganalisis peran Pusat Kegiatan Belajar Masyarakat dalam Mengatasi Masalah Sosial. Penelitian ini menggunakan metode penelitian kualitatif dengan pendekatan deskriptif analisis. Pengumpulan data dalam penelitian ini menggunakan bentuk observasi, wawancara, dan dokumentasi. Sampel dalam penelitian ini menggunakan metode multiple stage random sampling-teknik analisis data melalui pengumpulan data, reduksi penyajian data, dan penarikan kesimpulan. Fokus utama Community Learning Center dalam penelitian ini adalah tiga Community Learning Center utama.Berdasarkan data dan analisis penelitian, dapat disimpulkan bahwa Pusat Kegiatan Belajar Masyarakat di Kabupaten Sumedang untuk mengatasi kemiskinan melalui pendidikan nonformal berupa program-program yang bernilai dan praktis, sedangkan kegiatan lain di bidang pembangunan dan pemberdayaan masyarakat sudah ada namun masih belum optimal.
\end{abstract}

\section{INTRODUCTION}

Education essentially begins with an informal education path since childhood which refers to an educational activity that starts from the family and the environment. Then, someone enters formal education (Pillai et al., 2021; Freeman \& Dmytriyev, 2017). However, various factors undoubtedly limit formal teaching, including the period of students, place, and time. Because of this, the opportunity to experience formal education has not been felt by all circles of society even though the government has made a compulsory education program for nine years (Hiremath et al., 2020; Aliyyah et al., 2020). Consequently, there are still illiterate people. Even in 2019, illiteracy was still relatively high, namely

${ }^{1}$ UIN Sunan Gunung Djati Bandung, Indonesia

Email: endahchotim@uinsgd.ac.id 
1.78 per cent or around 3,081,136 people. Still, it was pretty reduced in 2020 to 1.71 per cent or approximately 2,961,060 people; the Director-General of Early Childhood Education conveyed this. Primary Education and Secondary Education (Dirjen PAUD Dikdasmen). From these data, of course, there is a need for the role of institutions such as the Center for Community Learning Activities to overcome this.

In general, the centre of community learning activities is an institution engaged in developing the world of non-formal education, which aims to become a centre that accommodates the community for learning (Rapanta et al.,2020). The primary function of the Community Learning Activity Center is to focus on two main things, namely, the centre for community activities and a place to find solutions to social problems that exist in society (McCullick \& Tomporowski, 2017). In its implementation, the Community Learning Activity Center operates as a social organization that seeks to reduce significant issues such as the backwardness of people's thinking patterns and has an essential role in other problems that require practical handling (Idrus, 2020).

Legally, regulations regarding this matter are strengthened through the Education System Law number 20 of 2003, which is expressly stated in Article 26 paragraphs (1) and (2), namely: (1) nonformal education is provided for community members who need educational services that function as a substitute, add-on, and complement formal education to support lifelong education; (2) non-formal education functions to develop the potential of students with an emphasis on mastery of knowledge and functional skills as well as the development of professional attitudes and personalities (Nurleni \& Widiastuti, 2018).

Non-formal education in the Community Learning Activity Center program includes life skills education, early childhood education, youth education, women empowerment education, skills education, equality literacy education, job training education, and so on, which was initially established at the sub-district level (Yanti \& Sunarti, 2021).

People who do not get an education proportionally can cause social problems on a broad scale, including poverty and unemployment problems. Based on data from the Central Statistics Agency, in 2020, the TPT (Open Unemployment Rate) in Indonesia reached a very high figure of 7.07 per cent or around 9.77 million people out of a total 138.22 million workforce. Three-year data on the number of unemployed are presented in the following figure:

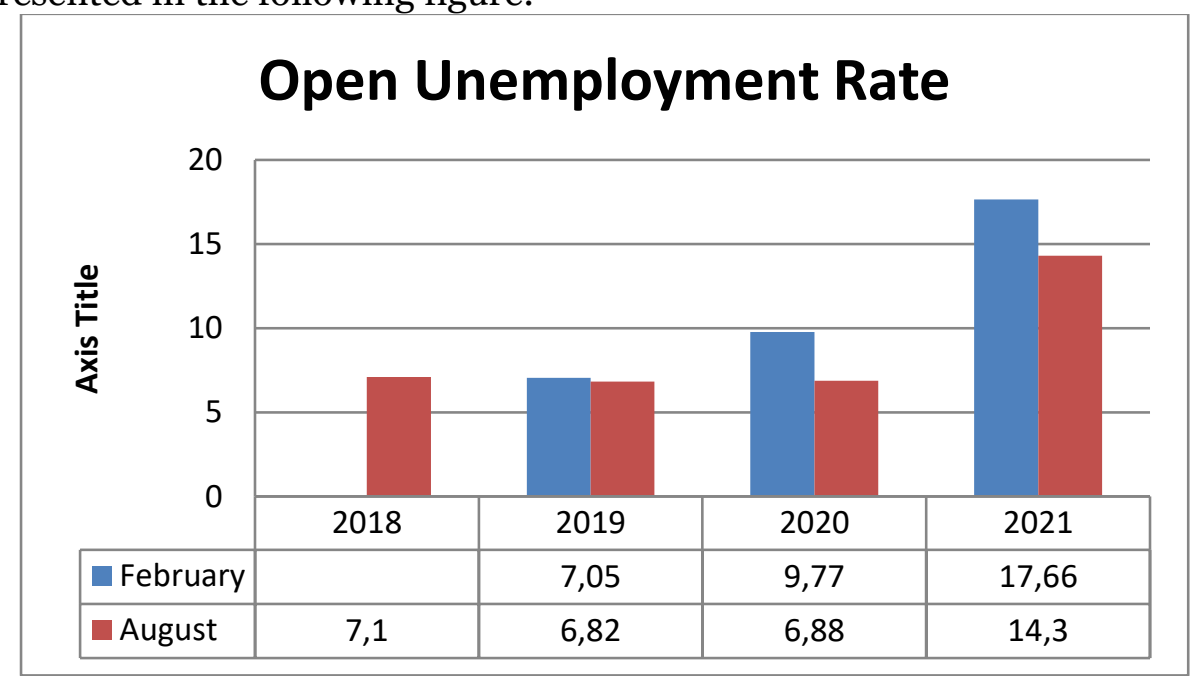

Figure 1. Open Unemployment Rate (2018-2020)

Source: data proceed

The presence of non-formal education can be a solution to these social problems because of its role as a substitute and complement to formal education. Thus, non-formal education implements the concept of lifelong education that can create a broad and implementable learning community culture. In other words, the Community Learning Activity Center provides learning opportunities for the community to foster a culture of independence, improve the quality of life, and develop communities in the community.

Among the tasks of the Community Learning Activity Center are: 1) identifying and addressing community needs, 2) meeting the needs and interests of the community through various activities, 3) mobilizing resources in the community, 4) building close cooperative relationships and partnerships with other organizations and institutions. ,5) monitor and review progress to assist in future planning, 
and 6) document the strengths and weaknesses of the Community Learning Activity Center activities. Various ways for countries to eradicate poverty and hunger through sustainable food production and consumption have been defined in sustainable development goals. The commitment of governments to increase the world's population in an environmentally friendly manner is a challenge for some developing countries (Park et al.,2018; Tsompanaki \& Lykesas, 2020).

Another social problem is poverty; this problem is the most serious in the economic development program that the Indonesian people are facing, and getting out of this problem, the government has made various serious efforts to overcome poverty, including the Hope Family Program (PKH), the National Program for Empowerment Community (PNMP) up to a budget of IDR 17 trillion. However, the government's efforts are still not optimal and are significant in terms of results, and the poverty rate is still very high (Utami \& Suyatmi, 2017; Haruna, 2018). From the data in Figure 1 above, the very high number of unemployed is closely correlated with the poverty rate in Indonesia; the poverty data in Indonesia can be seen in the following figure:

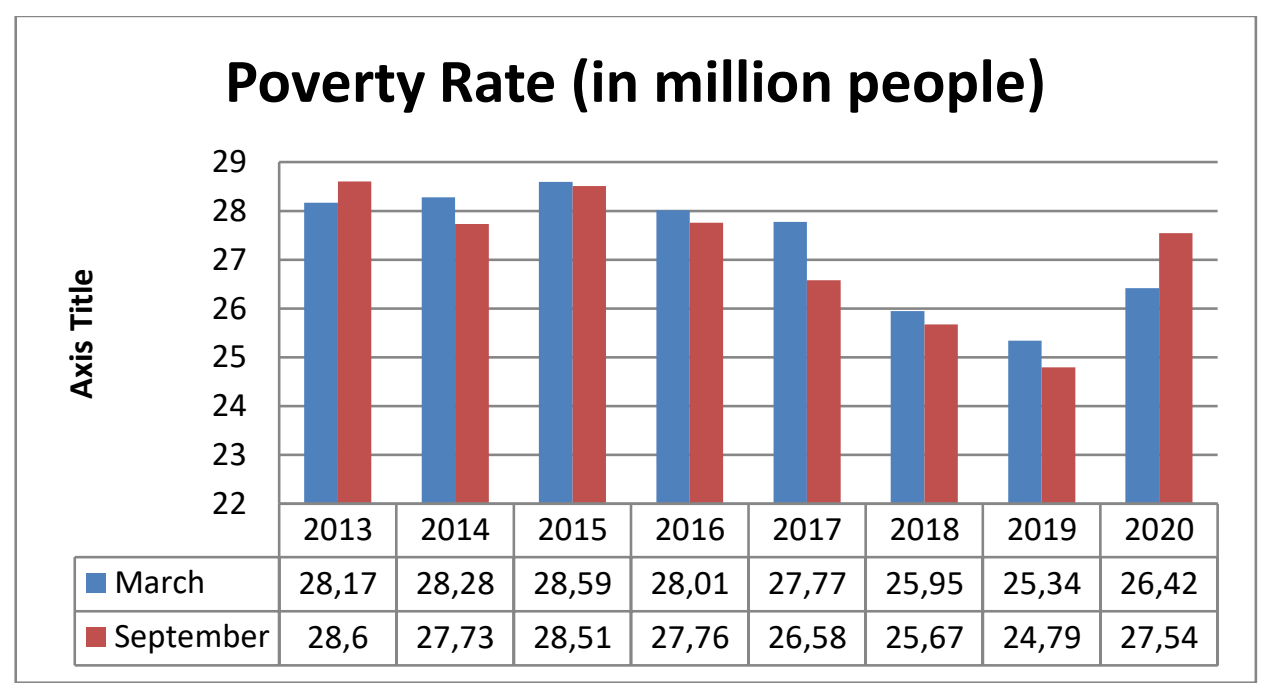

Figure 2. Poverty Rate (2013-2020)

Source: data proceed

Based on the data above, the number of people classified as poor increased by about 0.86 million people, so that some economic observers said that the figure. The increasing needs of the people and the world recession that lasts for a long time will make it challenging to increase development funds (Anggraini, 2018; Sumarlin \& Baehakki, 2020). Some of the reasons for the growth and development of Community Learning Activity Centers are several factors: 1) the lack of natural government ability to reach the lowest layers in the national development process; 2) There is a spirit to serve and serve community members. Meanwhile, the other roles of self-help are: 1) as a catalyst; 2) educators; 3) booster for self-supporting capital fertilization, and 4) conducting incentive projects. In carrying out its role, the Center for Community Learning Activities is engaged in a system that follows government programs (Nawindah et al.,2021; Ridwan, 2017). The Community Learning Activity Center activities generally try to improve the welfare of the community members who are categorized as poor and underdeveloped. The role of the Community Learning Activity Center also aims to enhance the interest of every community member who is the target. It is hoped that the community will take responsibility for the implementation of development (Sjamsir, 2021). The form of community participation appears to be the Community Learning Activity Center activity, which helps some community members who are classified as poor and underdeveloped.

\section{METHODS}

This study uses a qualitative research method with a descriptive analysis approach. Collecting data in this study using the method of observation, interviews, and documentation. The sample in this study used a multiple-stage random sampling method. The object of this research is the Center for Community Learning Activities located in the Sumedang district, which conducts poverty alleviation activities and other social problems in the area. The data validity technique uses triangulation of sources, methods, and theories-data analysis techniques through data collection, data presentation 
reduction, and concluding. The main focus of the Community Learning Activity Center in this study were three main Community Learning Activity Centers, namely: 1) Jembar Kabisa Community Learning Center; 2) Guna Darma Community Learning Center; and 3) Cigembong Community Learning Center.

\section{FINDINGS AND DISCUSSION}

\section{Poverty Reduction Program Development}

The primary function of the Community Learning Activity Center is as a community activity center that plays an alternative position for the community. Various solutions to community problems that cannot be found in formal education can be found and implemented in this non-formal education. Based on research conducted on the Center for Community Learning Activities in the Sumedang district, each has a program related to poverty alleviation and can be implemented and felt the impact as soon as possible.

Types of non-formal education include life skills education, early childhood education, youth education, women's empowerment education, literacy education, skills education/courses, and job training (Karim, 2017). These various types of programs are generally found at the Community Learning Activity Center. For example, equality education includes Package A, Package B, and Package C, as well as other education aimed at developing students' abilities such as course institutions, training institutions, study groups, taklim assemblies, studios, and so on, as well as other education aimed at developing students' abilities (Widiastuti, 2018). Various programs in the Community Activity Center include many practical things such as equality programs, literacy, skills, courses or training, entrepreneurship, car steering training (driver can get SIM A), motorbike driving (can get SIM C), foreign languages, carrier events, fashion designers, embroidery, ribbon embroidery, beauty, bridal makeup, delivery creations, various handicrafts, garnishes, office computers, graphic design, computer technicians, catering and various handicrafts. In addition, there are also programs in the form of managing potential local products (such as processing Carica fruit, cassava, and freshwater fish).

Likewise, at the Guna Darma Community Learning Activity Center, the types of programs range from Early Childhood Education (PAUD), Equality Program (package B \& package C), Tutoring, Courses, and Business Learning Groups (KBU). The field also found that the Jenggala Community Learning Center is more oriented towards Course Programs. Various programs can be served in the morning, afternoon, evening, and night. Types of Programs The courses include; Windows computer courses, graphic design \& AutoCAD, English, Accounting, Sewing, Electronics, Car steering (SIM A management), Abacus, Motorcycle mechanic, Car mechanic, Computer technician, Mobile technician, Swimming, and Hospitality.

The Guna Darma Community Learning Activity Center also has an Early Childhood Education program whose building is close to the Course Institute. Several buildings are designed to be used for the operational activities of the Guna Daram Community Learning Center program. Residents previously owned several buildings then rented, and the Community Learning Activity Center purchased some. The top-rated programs are the car driving program, acquiring a Driving License A, and Early Childhood Education. In addition, there is also a hotel program that has just opened for registration some time ago. Due to the number of enthusiasts, the Guna Darma Community Learning Activity Center owner has almost no time to rest.

Furthermore, the Cigembong Community Learning Activity Center has several Equality, PAUD, Courses, TBM, and KBU programs. This is as stated by Mr. IS, the manager and owner of the Community Learning Activity Center; the schedule here is the pursuit of package $\mathrm{C}$, the image of hope playgroup, community reading park, various sewing courses, computers, English, driving a car and a business learning group which includes tools educational and convection games. Each of these programs has been structured in an explicit curriculum. In the operational building, there is a photocopy machine, and it also functions as a place for competency testing in the field of fashion (McCombs \& Yoo, 2017). The flagship programs in the Cigembong Community Learning Activity Center are the steering wheel program, sewing courses, Early Childhood Education programs, and educational games and convection, which are pretty popular.

\section{Citizens' Learning Motivation in Participating in the Program}

The motivation of residents in learning and participating in programs in the Community Learning Activity Center tends to be varied. Some are active, mediocre, and even passive in the following education during tutorials. Not a few residents follow the tutorial without being involved 
in the learning process, which is used with the tutorial method accompanied by practice (Wardhana et al.,2020).

The presence of learning residents in participating in the program is still not consistent. Residents learning to follow the tutorial activities only leave for exams or semester tests, especially the package $\mathrm{C}$ pursuit program. The schedule of activities in implementing the package $\mathrm{C}$ pursuit program is carried out regularly on Fridays, Saturdays, and Sundays from 15.00 to 17.30. Previously, learning residents were contacted first by the homeroom teacher if there was a package C learning tutorial or not. They were not always present, but all learning residents would be current when there were exams and tests and other activities; for example, there were visits from the local government and the province. This is influenced by several things, including because they prefer to work rather than participate in package $\mathrm{C}$ activities, so residents learn to participate in package $\mathrm{C}$ if they have more time than their work. The motivation of retaining residents is driven by the existence of diploma rewards, the hope to continue to a higher level of education, the need for work.

As for other activities, the readiness of residents to participate in the program is influenced by two main factors, namely physical factors and psychological factors. The physical aspect of the physical and spiritual health conditions of the entire learning community is said to be good for receiving the material delivered by the tutor without any problems. Meanwhile, from the psychological aspect of learning citizens, it can be seen from the intelligence, talents, and interests of learning citizens. This is constrained by the lack of relevant human resources and costs. In meeting their learning needs, there are several obstacles that are often faced, namely distance/place, time, different work backgrounds (Himayaturohmah, 2017). The motivation of the residents to learn at the Community Learning Activity Center can be seen from their activeness when they take part in learning, not a few of them are active and not even a few of them during the learning process are cool on their own with things outside of learning and some are even sleepy, talking to themselves so did not pay attention to the material presented by the tutor (Baldridge et al.,2017).

The motivation of learning residents is driven by the existence of diploma rewards, the hope to continue to a higher level of education, the need for work. In addition to costs to support infrastructure activities in the learning process, it is also necessary for the smooth running of activities, so that learning residents in participating in activities can implement in their daily life what is obtained when participating in programs available at the Community Learning Activity Center. Infrastructure facilities such as module books, libraries, learning media, and other supporting facilities have not been fully fulfilled to facilitate learning residents.

From the findings above, there are two types of motivation, namely intrinsic motivation and extrinsic motivation, which are naturally owned by every human being. This is in line with the theory of Patton (1961) in Denim (2004: 28). According to Patton, motivation is influenced by two things, namely the individual himself and the situation he faces. In other words, there are two factors that influence human motivation at work, namely internal and external motivation. As explained above, the motivation of citizens to learn is different. The indifferent attitude of those who, for some reason they behave like that, actually need educational services that can accommodate the community.

Learning residents who can be said to have low motivation can be seen from several indicators such as choosing to be indifferent, easily discouraged, their attention is not focused on the lesson, likes to disturb the class, often leaving lessons as a result, many have learning difficulties. In meeting their learning needs, there are several obstacles that are often faced, namely distance/place, time, different work backgrounds.

\section{The Role of Community Learning Activity Centers in Reducing Poverty through Non-Formal Education}

Poverty occurs as a result of the powerlessness of community members to access skills into needed goods. Therefore, the Community Learning Activity Center is used as a centre for nonformal education forums to find solutions to these kinds of problems so that the community's needs can be met. That way, poverty can be reduced because people are able to get their needs that can be accessed very affordably. The programs developed at the Community Learning Activity Center are of course, real in nature, and as soon as possible, they can be implemented and their impact felt. One of the goals of organizing the Community Learning Activity Center is to empower 
the community. By being empowered, they are able to meet their respective needs and are not too dependent on others. It is this capability that is intended to be formed from the activities of the Community Learning Activity Center through its programs.

With its programs, the Community Learning Activity Center can overcome poverty in the community. This can happen to access to formal education that is not easily accessible, which eventually they drop out of school and have low education making their powerlessness appear. Powerlessness is the root of poverty. The KBU program can open up business opportunities for graduates of learning citizens (alumni) to form business groups. That way he doesn't have to work alone in entrepreneurship, and at the same time he doesn't feel heavy compared to having to start his own business, especially with personal capital (Irmawati, 2017). This is what can then be felt that the Community Learning Activity Center programs can tackle poverty appropriately.

This is so, especially if from the institution there is a guarantee of job placement after the course or training or learning process it will make it much easier for alumni learning residents to immediately work and earn income which is ultimately far from poverty. With this condition he is empowered because he is able to use his own abilities to get something he wants.

For example, for the sewing program, the Jembar Kabisa Community Learning Center has several partners, such as many home industries around the operational area. Usually, if there are alumni who have passed, they will be operated on by the partner. However, this still encounters several obstacles, including the number of applicants and alumni who are too many so that not all graduates can be accessed to be placed in partner institutions. The results of the current course learning process must be guaranteed until a competency test is used that the learning community really has competence in the field that is being occupied and developed (Sunarsi, 2018). Various courses have had competency tests, thus ensuring that graduates are more competent in certain fields.

From a conventional point of view, to measure the success of a learning process, it is enough to look at the existence of a diploma for a formal school. Perhaps the certificate is only charged and evaluated internally, with the competency test being evaluated by an external party who has the capacity in the field. By being tested and evaluated by external parties (external), the ability of citizens to learn is more secure because when they graduate, they are required to work by institutions outside the institution they are studying. Thus the Competency Certification Institute (LSK) can measure the achievement of competence in various fields nationally. So there is a benchmark assessment used for standardization. So, if the development model for the Community Learning Activity Center is developed as shown in the following figure:

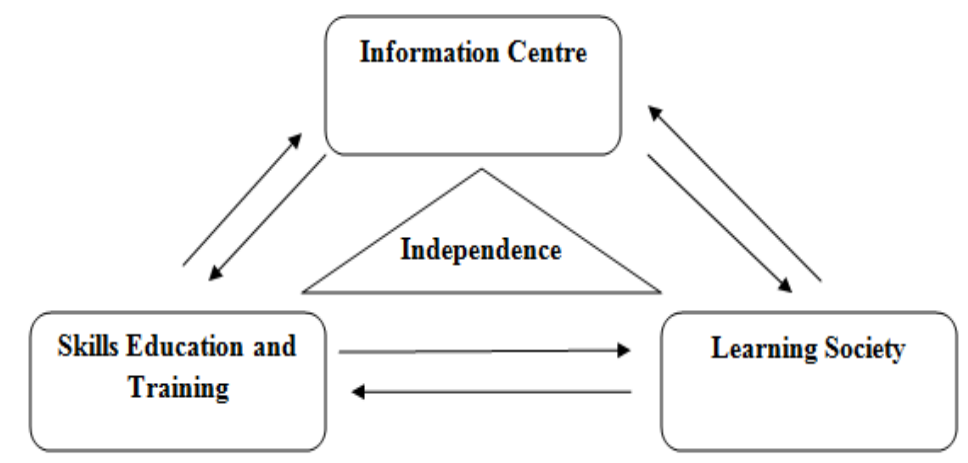

Figure 3. The Role of the Community Learning Center

The Community Learning Activity Center was formed from thinking about the awareness of the importance of the community's position in developing non-formal education so that it is expected to be the backbone for empowering the potentials that exist in the community. The Community Learning Activity Center is built based on community needs that emphasize selfreliance, cooperation, and community participation as a learning center. Especially those related to improving skills and intelligence (Shofwan et al.,2019; Sari et al.,2020).

The role of the Community Learning Activity Center in tackling poverty which has been described from the research results, can be stated that the role of the Community Learning Activity Center is very important as a forum for non-formal education learning that exists in the midst of society to present alternative solutions to various existing problems. In terms of the program, the type of entrepreneurship-based program is the most important solution in overcoming poverty 
which is oriented towards forming group independence through joint efforts. It is also believed that various types of courses can create businesses independently. As well as the existence of various supporting programs such as partnerships in distributing training graduates or alumni.

Partnerships can be in the form of the business world or the industrial world. There are at least three main things from the process, namely the presence of new information, skills training, and the result is independence. So that it can be found that the role of the Community Learning Activity Center is in addition to being a forum for community learning, exchanging information, an information center, and a community research center. Thus becoming a research center because it is the community as the subject and the object of the Community Learning Activity Center programs. The development of the Community Learning Activity Center program can also be obtained from studies (research that can be done) on the community itself. There are three main functions obtained and developed in the Community Learning Activity Center programs: new information, skills training, and independence. The type of training that is part of the curriculum in the Jembar Kabisa Community Learning Activity Center; Guna Darma Community Learning Center; and the Cigembong Community Learning Activity Center are presented in the following table:

Table 1. Types of programs developed by the Center for Community Learning Activities in alleviating poverty

\begin{tabular}{|c|c|c|c|}
\hline \multirow{2}{*}{ Program Type } & Jimbaran Kabisa & Gunda Darma & Cigembong \\
\cline { 2 - 4 } $\begin{array}{c}\text { Early childhood } \\
\text { pducation } \\
\text { programs }\end{array}$ & Children's Playgroup & Playgroup & $\begin{array}{c}\text { Early Childhood } \\
\text { Education Post }\end{array}$ \\
\hline Equality & Tutoring & Pursue Package C & $\begin{array}{c}\text { Pursue Package C } \\
\text { and Package D }\end{array}$ \\
\hline $\begin{array}{c}\text { Course and } \\
\text { training }\end{array}$ & $\begin{array}{c}\text { Computer, Graphic } \\
\text { Design, English, } \\
\text { Sewing, Electronics, } \\
\text { Auto mechanic, } \\
\text { Technician, Mobile } \\
\text { Technician, } \\
\text { Swimming and } \\
\text { Hospitality }\end{array}$ & $\begin{array}{c}\text { Sewing, Computer, } \\
\text { English and Car } \\
\text { Steering }\end{array}$ & $\begin{array}{c}\text { Karawitan, Bamboo } \\
\text { Crafts, Sundanese } \\
\text { Art, Bridal Makeup }\end{array}$ \\
\hline Apprenticeship & $\begin{array}{c}\text { Different types of } \\
\text { courses }\end{array}$ & $\begin{array}{c}\text { Different types of } \\
\text { courses and literacy }\end{array}$ & $\begin{array}{c}\text { Different types of } \\
\text { courses and literacy }\end{array}$ \\
\hline Other Programs & Sew & Sew & - \\
\hline
\end{tabular}

The various programs organized by the Center for Community Learning Activities should indeed be able to overcome poverty. The program developed is built on the needs of the learning community. The various curricula that have been prepared are flexible and varied to establish the competence of learning citizens because the Community Learning Activity Center is one of the government's partners who must participate in educating people's lives through various programs that are expected to be able to grow a learning community with an innovative spirit to create independence and empowerment (Rimbarizki \& Susilo, 2017).

As the research results, the types of programs developed by the Center for Community Learning Activities in tackling poverty are PAUD programs, Equality, Literacy, Courses and Training, KBU, Internships, and other programs. Several programs developed by the Community Learning Activity Center are in the field of non-formal education, which is the mainstay program of the Community Learning Activity Center, namely functional literacy programs, early childhood development, equality programs, business learning groups, development of internship programs, skills courses and the Community Learning Activity Center program in outside the program of the Ministry of National Education.

Of course, it will be different if it is understood, the Community Learning Activity Center is an institution that is managed directly by the community even though it is owned by someone. However, all the great participation of the community is certainly aimed at the Community Learning Activity Center which is a learning centre in the midst of society. There are three important objectives in the context of establishing and developing Community Learning Activity 
Centers; (1) empowering the community to be able to be independent (empowered), improve the quality of life of the community both from a social and economic perspective, and (2) increase sensitivity to problems that occur so that they can be solved.

\section{Supporting and Inhibiting Factors}

The factors that influence the learning community in participating in various Community Learning Activity Center programs are divided into internal and external factors. Internal factors that influence the motivation of learning residents are their physical and physiological conditions, feeling happy, enthusiastic in participating in their activities, the physical and spiritual health of healthy learning residents so that in receiving the material provided by the tutor, they are able to process and obtain satisfactory results. With satisfactory results, learning residents feel more motivated and believe in their own abilities to achieve the expected goals (Nim, 2018). In contrast, the external factors are the environment, family background, parental education level, and economy.

The environment in question is the social environment of the community, family, school/study place, and peers, where residents learn to interact and socialize daily in meeting their needs. In this case, the social environment of the community and family strongly supports the existence of a package $\mathrm{C}$ pursuit program and work or foreign language learning so that it does not make it difficult for residents to learn to follow the program. The community feels happy and proud of the implementation of new programs such as package $C$ or language education so that people who have never received high school education, drop out of school, and dropouts can experience it through non-formal education.

Another factor that also influences parents' education factor for the learning community. The lack of knowledge base of parents who do not pay attention to education and science. In general, they are from poor farming families because the cost of getting an education is quite expensive (Almaidah, 2017). Differences in the characteristics of learning residents also affect the motivation of learning citizens in participating in the program, a difference that is very visible from the maturity of learning residents during tutorials.

This is in line with the theory put forward by Abraham H. Maslow, better known as Maslow's hierarchy of needs theory. Abraham H. Maslow argues that there are internal needs that greatly affect human motivation at work. Maslow argues that needs are arranged as a hierarchy consisting of five levels of needs, which are hierarchical in nature. The levels of needs according to Maslow are: level 5: self-actualization or realization, level 4: respect, level 3: sense of inclusion, love, and social activity, level 2: security, level 1: physical or biological. That's how human needs, according to Maslow. Humans will always fulfil the next need after the first need has been met (Arifah \& Maziyah, 2020; Octaviani et al.,2018).

In addition to the obstacles, of course, there is also support. Support can also come from internal and external. What was conveyed by the manager of the Community Learning Activity Center was that the internal support at the Community Learning Activity Center was that there were regular monthly meetings held by the divisions of each program, then adequate facilities and infrastructure that supported the implementation of the program as well as the availability of suitable places and equipment. For external support, there are partners who work well with the Center for Community Learning Activities, both from government institutions and private institutions. In addition to internal support which is the main factor forming an institution, there are also external factors. This support is a variety of support provided by both local governments, communities, private parties who want to participate and work together to form partnerships and their publications in the general media (Widiastuti, 2018). Until the commitment to take action such as branding the institution with a certain name makes its own stimulus in gaining the power to develop an institution in the midst of the wider community.

\section{CONCLUSION}

Based on the data and research analysis, it can be concluded that the Community Learning Activity Center in Sumedang district is the Jembar Kabisa Community Learning Activity Center; Guna Darma Community Learning Center; and the Cigembong Community Learning Activity Center to overcome poverty through non-formal education in the form of useful and practical programs, while other activities in the development and community empowerment sector exist but are still not optimal. 


\section{REFERENCES}

Aliyyah, R. R., Rachmadtullah, R., Samsudin, A., Syaodih, E., Nurtanto, M., \& Tambunan, A. R. S. (2020). The perceptions of primary school teachers of online learning during the COVID-19 pandemic period: A case study in Indonesia. Journal of Ethnic and Cultural Studies, 7(2), 90109.

Almaidah, S. (2017). Analisis Efektivitas Kinerja Pusat Kegiatan Belajar Masyarakat (PKBM) Dalam Menyelenggarakan Program Pendidikan Berbasis Masyarakat.Media Ekonomi dan Manajemen, 32(2).

Anggraini, W. W. (2018). Efektivitas Program Pendidikan Luar Sekolah Dalam Kejar Paket C Di Pusat Kegiatan Belajar Masyarakat "Variant Centre" Kelurahan Petemon Kecamatan Sawahan Kota Surabaya. Aplikasi Administrasi: Media Analisa Masalah Administrasi, 2o(1), 39-51.

Arifah, M., \& Maziyah, S. (2020). Peranan Pusat Kegiatan Belajar Masyarakat (PKBM) Karangmlati dalam Pengembangan Industri Kecil dan Menengah (IKM) Batik Demak 20092017. Historiografi, 1(2), 181-190.

Baldridge, B. J., Beck, N., Medina, J. C., \& Reeves, M. A. (2017). Toward a new understanding of community-based education: The role of community-based educational spaces in disrupting inequality for minoritized youth. Review of Research in Education, 41(1), 381-402.

Freeman, R. E., \& Dmytriyev, S. (2017). Corporate social responsibility and stakeholder theory: Learning from each other. Symphonya. Emerging Issues in Management, (1), 7-15.

HARUNA, C. N. (2018). Efektivitas Program Pendidikan Kesetaraan Paket B Dan C Oleh Pusat Kegiatan Belajar Masyarakat (PKBM) Cendikia Di Kabupaten Pangandaran. Moderat: Jurnal Ilmiah Ilmu Pemerintahan, 4(3), 53-63.

Himayaturohmah, E. (2017). Strategi Pengembangan Manajemen Pengelolaan Pusat Kegiatan Belajar Masyarakat (Pkbm) Di Provinsi Riau. Jurnal Penjaminan Mutu, 3(1), 100-110.

Hiremath, P., Kowshik, C. S., Manjunath, M., \& Shettar, M. (2020). COVID 19: Impact of lock-down on mental health and tips to overcome. Asian Journal of Psychiatry, 51, 102088.

Idrus, A. (2020). Turnitin/Review/Korespondensi The Effect of Self-Effcacy and Entrepreneurship on Manajers' Professionalisme and Performance in Jambi Community Learning Centers'.

Irmawati, A. (2017). Peran Pusat Kegiatan Belajar Masyarakat (Pkbm) dalam Mengurangi Buta Aksara di Kabupaten Karimun*. Jurnal Pendidikan dan Kebudayaan, 2(1), 81-98.

Karim, A. (2017). Efektivitas Partisipasi Perempuan Pada Pendidikan Non Formal di Pusat Kegiatan Belajar Masyarakat (PKBM) Kecamatan Wedarijaksa Kabupaten Pati. INFERENSI: Jurnal Penelitian Sosial Keagamaan, 11(1), 119-140.

McCombs, J. S., Whitaker, A., \& Yoo, P. (2017). The value of out-of-school time programs. Santa Monica, CA: Rand Corporation.

McCullick, B. A., \& Tomporowski, P. D. (2017). The Physical Activity and Learning Program and the 21st Century Community Learning Centers Initiative. Physical Activity and Learning After School: The PAL Program, 1.

Nawindah, N., Ujiandari, R., \& Fajarita, L. (2021). Peningkatan Pemahaman Sumber Daya Manusia Melalui Pelatihan Dasar Zahir For Accounting 1 Pada Pusat Kegiatan Belajar Masyarakat. IKRAITH Abdimas, 4(1), 34-41.

Nim, A. S. P. (2018). Peran Pusat Kegiatan Belajar Masyarakat (Pkbm) Harapan Bangsa Dalam Meningkatkan Kemandirian Warga Binaan Melalui Social Entrepreneurship Di Kelurahan Parit Tokaya Kecamatan Pontianak Selatan Kota Pontianak. SOCIODEV-Jurnal Ilmu Sosiatri (Pembangunan Sosial), 7(3).

Nurleni, A., \& Widiastuti, N. (2018). Peran Pusat Kegiatan Belajar Masyarakat PKBM dala Memberdayakan Masyarakat Melalui Pelatihan Tata Boga.dalam Jurnal Comm Edu. Bandung: IKIP Siliwangi.

Octaviani, V., Narti, S., \& Nurwita, S. (2018). Peningkatan sumber daya masyarakat desa dalam binaan pusat kegiatan belajar masyarakat (PKBM). Jurnal Pengabdian Pada Masyarakat, 3(2), 117124.

Park, J., Hwang, G., \& Cho, J. (2018). Barriers and improvements to promoting physical activity among children using community child care centers: Perspectives of service providers. Journal of Korean Public Health Nursing, 32(1), 109-121. 
Pillai, V., Pandey, M., \& Bhatt, B. (2021). Social Sustainability at the BOP Through Building Inclusive Social Capital: A Case Study of Drishtee. In Sharing Economy at the Base of the Pyramid (pp. 301-318). Springer, Singapore.

Rapanta, C., Botturi, L., Goodyear, P., Guàrdia, L., \& Koole, M. (2020). Online university teaching during and after the Covid-19 crisis: Refocusing teacher presence and learning activity. Postdigital Science and Education, 2(3), 923-945.

Ridwan, I. (2017, May). Eksistensi Pusat Kegiatan Belajar Masyarakat Berbasis Sumber Daya Lokal Dalam Pembangunan Pendidikan. In Prosiding Seminar Nasional Pendidikan FKIP (Vol. 1, No. 2).

Rimbarizki, R., \& Susilo, H. (2017). Penerapan pembelajaran daring kombinasi dalam meningkatkan motivasi belajar peserta didik paket $\mathrm{C}$ vokasi di pusat kegiatan belajar masyarakat (PKBM) Pioneer Karanganyar. J+ Plus Unesa, 6(2).

Sari, I. P., Nugroho, A., Sari, S. M., Maryani, K., \& Fitri, E. W. (2020). Pendampingan Pembentukan PKBM (Pusat Kegiatan Belajar Masyarakat) di Desa Mandiangin Kecamatan Rawas Ilir Kabupaten Musi Rawas Utara. Jurnal Pengabdi, 3(1), 40-50.

Shofwan, I., Yusuf, A., Suryana, S., \& Widhanarto, G. P. (2019). Evaluasi Program "Model Logical Framework" untuk Pengelola Pusat Kegiatan Belajar Masyarakat (PKBM). Jurnal Panjar: Pengabdian Bidang Pembelajaran, 1(1), 59-64.

Sjamsir, H. (2021). Manajemen Pusat Kegiatan Belajar Masyarakat. BEduManageRs Journal, 2(1), 614.

Sumarlin, S., \& Baehakki, I. (2020). Analisis Kompetensi Pedagogik Dan Profesional Tutor Terhadap Hasil Belajar Warga Belajar Pendidikan Kesetaraan Paket C (Studi Pada Pusat Kegiatan Belajar Masyarakat Bahtera Dua Blitar). REVITALISASI: Jurnal Ilmu Manajemen, 9(1), 100-106.

Sunarsi, D. (2018). Analisis Motivasi Kerja Tenaga Pendidik Sukarela Pada Pusat Kegiatan Belajar Masyarakat (PKBM) Bimasda Kota Tangerang Selatan. Kreatif: Jurnal Ilmiah Prodi Manajemen Universitas Pamulang, 6(2), 53-65.

Tsompanaki, E., \& Lykesas, G. (2020). Effect of Community Dance on Children's Socialization in Creative Activities Centers. Sport Science, 14(1), 79-88.

Utami, E., \& Suyatmi, S. (2017). IbM Pusat Kegiatan Belajar Masyarakat-Pkbm [Ibm Center of Community Learning]. Jurnal Sinergitas PKM \& CSR, 2(1), 1-14.

Wardhana, L. W., Ambarwati, D., \& Sholihin, U. (2020). Preliminary observation study of Kampung Tahu in Tinalan Village, Kediri City, for implementation of educational tourism village concept based on industrial centers. KnE Social Sciences, 51-65.

Widiastuti, N. (2018). Peran Pusat Kegiatan Belajar Masyarakat (Pkbm) Dalam Memberdayakan Masyarakat Melalui Pelatihan Tata Boga (Study Kasus di PKBM Bina Mandiri Cipageran). Comm-Edu (Community Education Journal), 1(2), 1-6.

Widiastuti, N. (2018). Peran Tokoh Masyarakat Dalam Meningkatkan Pendidikan Di Pusat Kegiatan Masyarakat (PKBM) Bina Mandiri Cipageran Kecamatan Cimahi Utara. Comm-Edu (Community Education Journal), 1(2), 65-71.

Yanti, V. R., \& Sunarti, V. (2021). Hubungan Keterampilan Mengajar Tutor dengan Hasil Belajar Pendidikan Kesetaraan Paket C pada Peserta Didik di Pusat Kegiatan Belajar Masyarakat (PKBM) Media Kabupaten Pesisir Selatan. Jurnal Pendidikan Tambusai, 5(1), 1394-1404. 